\title{
HAK ANGKET DEWAN PERWAKILAN RAKYAT REPUBLIK INDONESIA (DPR RI) TERHADAP KOMISI PEMBERANTASAN KORUPSI (KPK)
}

\author{
Dasep Muhammad Firdaus \\ Pascasarjana UIN Sunan Gunung Djati Bandung \\ Email :dasepmf@gmail.com
}

\begin{abstract}
Indonesia as a constitutional and democratic state has three governmental branches which are executive, legislative and judicial power; and executed on the check and balance principle. One of the check and balance principles implementation can be seen in the House of Representatives of Indonesia (DPR)'s Parliamentary Scrutiny function which is mandated by the 1945 Constitution of the Republic of Indonesia (UUD 1945), the right of inquiry to investigate all forms of implementation of laws and government policies that are allegedly contrary to the legislation. Recently the rights had been applied to evaluate KPK (corruption eradication comission) as an independent institution and free from any authority. Substantially the inquiry right was applied to evaluate KPK regarding the following aspects: institutional, authority, human resources and expenditure budgets. Through legal tracing on related laws and regulations, that were descriptively analyzed regarding the DPR's inquiry right implementation towards KPK; it was found the DPR's inquiry rights to the KPK is constitutionally regulated in Article $20 \mathrm{~A}$ of the UUD 1945, Law Number 17 of 2014 Article 79 paragraph (1), (2) and (3) and Constitutional Court Decision Case No. 36 and 37 / PUU-XV / 2017. Based on those regulations, DPR has rights to ask for KPK's accountability upon their duties and authority and KPK is obliged to respect and implement DPR recommendations produced from the inquiry rights.
\end{abstract}

Keywords:

People's Representative Council, Rights of Inquiry, Corruption Eradication Commission

\begin{abstract}
Abstrak
Indonesia sebagai negara demokrasi kontitusional terdiri dari cabang kekuasaan eksekutif, legislatif, dan yudikatif berdasar prinsip check and balance. Wujud prinsip tersebut ada dalam ketatanegaraan Indonesia terlihat pada fungsi pengawasan DPR RI yang diamanatkan oleh UUD NRI Tahun 1945, antara lain melalui hak angket untuk menyelidiki segala bentuk pelaksanaan UU maupun kebijakan pemerintah yang diduga bertentangan dengan peraturan perundang-undangan. Salah satunya adalah hak angket yang ditujukan terhadap KPK sebagai lembaga bersifat independen dan bebas dari kekuasaan manapun. Secara subtantif pelaksanaan hak dilakukan untuk mengevaluasi KPK dari sisi kelembagan, kewenangan, sumber daya manusia hingga anggaran belanja. Melalui penelusuran peraturan perundang-undangan yang dianalisis secara deskriptif atas hak angket DPR terhadap KPK; ditemukan bahwa landasan hukum hak angket DPR terhadap KPK secara konstitusional diatur di dalam Pasal 20A UUD NKRI Tahun 1945, Undang-Undang Nomor 17 Tahun 2014 Pasal 79 ayat (1), (2) dan (3) dan Putusan MK No. Perkara 36 dan 37/PUU-XV/2017. Atas dasar ketentuan tersebut, DPR berhak meminta pertanggungjawaban pelaksanaan tugas dan kewenangan KPK dan KPK sebagai
\end{abstract}


lembaga penegak hukum harus menghormati dan melaksanakan rekomendasi yang telah dihasilkan pansus angket dan.

\section{Pendahuluan}

Kata Kunci:

$D P R$, Hak Angket, KPK

Demokrasi konstitusional sebagai suatu program dan sistem politik yang konkret muncul pada akhir abad ke-19, dengan gagasan pemerintah yang demokratis adalah pemerintah yang terbatas kekuasaannya dan tidak dibenarkan bertindak sewenangwenang terhadap warganegaranya. Indonesia adalah negara hukum atau constitutional state yaitu Negara yang dibatasi oleh konstitusi. ${ }^{1}$ Implementasi dari fungsi hukum sebagai sarana kontrol sosial dan perekayasa sosial di dalam sistem ketatanegaraan Indonesia berdasarkan UUD 1945 diharapkan mengubah konsep-konsep dasar dan muatan materi yang mengatur sistem pemerintahan Negara, baik mengenai pengaturan tentang kedudukan, tugas, wewenang maupun hubungan antar lembaga Negara, yang diharapkan memunculkan suasana "checks and balances".

Oleh karena itu menurut Montesqueiu dengan teori trias politica-nya, antara lembaga legislatif, eksekutif dan yudikatif tidak ada lagi yang dominan dalam menjalankan pemerintahan. Eksekutif dalam menjalankan kebijakannya selalu dipantau oleh legislatif, di Indonesia disebut Dewan Perwakilan Rakyat (DPR). ${ }^{2}$

Terdapat tiga fungsi utama DPR, ketiga fungsi utama tersebut adalah fungsi legislasi, fungsi anggaran, dan fungsi pengawasan. Pengawasan (controlling) yaitu suatu kegiatan yang ditujukan untuk menjamin agar penyelenggaraan negara sesuai dengan rencana. Jika dikaitkan hukum pemerintahan, pengawasan dapat diartikan sebagai suatu kegiatan yang ditujukan untuk menjamin terlaksananya penyelenggaraan negara oleh lembaga-lembaga kenegaraan sesuai dengan hukum yang berlaku. Tolak ukur suatu kontrol politik (pengawasan) berupa nilai-nilai politik yang dianggap ideal dan baik (ideologi) yang dijabarkan dalam kebijakan atau undang-undang. Tujuannya adalah meluruskan kebijakan atau pelaksanaan kebijakan dan pelaksanaannya sejalan dengan tolak ukur tersebut. Fungsi kontrol merupakan konsekuensi logis dalam sistem demokrasi dalam memperbaiki dirinya. ${ }^{3}$

Selain ketiga fungsi di atas, secara Konstitusional DPR memiliki hak yang melekat kepadanya. Dalam ketentuan Undang-Undang Dasar Negara Republik Indonesia Tahun 1945 (UUD NRI Tahun 1945) hak DPR adalah Hak Interpelasi, Hak Angket, dan Hak Menyatakan Pendapat. ${ }^{4}$ Hak Angket adalah hak anggota badan

\footnotetext{
${ }^{1}$ Jimly Assdiddiqie, Pengantar Ilmu Hukum Tata Negara, Cet.ll, (Jakarta: Rajawali Pers, 2010), hlm. 281

${ }^{2}$ Sri Soemantri, dkk, Ketatanegaraan Indonesia Dalam Kehidupan Politik Indonesia: 30 Tahun kembali ke Undang-Undang Dasar 1945, Cet.1, (Jakarta: Pustaka Sinar Harapan, 1993), h 281.

3 Padmo Wahjono, Indonesia Negara Berdasarkan Atas Hukum, cet.II, (Jakarta: Ghalia Indonesia, 1983), hlm.82

${ }^{4}$ Pasal $20 A$ ayat 2, Undang-Undang Dasar Negara Republik Indonesia Tahun 1945.
} 
legislatif untuk mengadakan penyelidikan terhadap kebijakan pemerintah yang penting dan strategis serta berdampak luas pada kehidupan bermasyarakat dan bernegara yang di-duga bertentangan dengan peraturan perundang-undangan.

Pada sidang paripurna DPR yang diadakan pada Jumat 28 April 2017, Fahri Hamzah, Wakil Ketua DPR, telah mengetuk palu tanda hak angket DPR terhadap KPK terkait dengan penolakan KPK membeberkan rekaman pemeriksaan Miryam dalam kasus korupsi e-KTP yang menyebutkan adanya bagi-bagi duit kepada anggota DPR dalam proses penganggaran e-KTP yang kemudian disanggah dan mencabut Berita Acara Pemeriksaan (BAP) KPK karena adanya tekanan dari penyidik hak angket juga diajukan karena ingin menyelidiki kinerja KPK hingga urusan anggaran belanja. ${ }^{5}$

Berdasarkan alasan tersebut di atas DPR menggunakan fungsi pengawasan dengan menggunakan hak angket terhadap Komisi Pemberantasan Korupsi (KPK). Namun terdapat berbagai pendapat yang menyatakan bahwa hak angket tersebut memilikikelemahan prosedur (formil) dan subtansi (materil). Tulisan ini ditujukan untuk menelusuri landasan hukum penerapan Hak Angket DPR RI terhadap KPK.

\section{Landasan Hukum Hak Angket DPR RI terhadap KPK}

Artinya, jangan sampai BAP tersebut jatuh ke tangan orang yang tidak bertanggung jawab dan menjadi konsumsi publik, sementara DPR terlalu jauh menggunakan hak angket supaya KPK membuka dokumen rahasia terhadap DPR berarti sudah mengintervensi lembaga penegak hukum. Tidak cukup sampai di situ apakah konteks isi hak angket itu berkaitan dengan hal penting, strategis, dan berdampak luas pada kehidupan bermasyarakat, berbangsa dan bernegara atau kepentingan anggota anggota DPR yang dilembagakan.

Hak angket merupakan hak Dewan Perwakilan Rakyat Republik Indonesia (DPR $\mathrm{RI}$ ) untuk menjalankan fungsinya. Penyelenggaraan hak angket menurut DPR RI sebagai bentuk perwujudan dari prinsip hukum tata negara yaitu check and balance. Konsep check and balance merupakan bagian dari hasil reformasi yang pada intinya ingin mewujudkan sistem perimbangan kekuasaan. Reformasi Mei 1998 memberikan banyak perubahan dalam ketatanegaran Indonesia, salah satunya adalah. ${ }^{6}$ Kesadaran memperkuat proses check and balance antara cabang-cabang kekuasaan telah berkembang sedemikian rupa bahkan melampui konvensi yang selama ini dipegang yakni asas kekeluargaan di dalam penyelenggaraan negara.

Hak angket DPR RI yang digulirkan kepada KPK sebagai wujud pengawasan DPR $\mathrm{RI}$ terhadap lembaga negara sekaligus wujud prinsip check and balance. Pengawasan (controlling) yaitu suatu kegiatan yang ditujukan untuk menjamin agar penyelenggaraan

\footnotetext{
${ }^{5}$ Syamsudin, Hak Angket DPR Terhadap KPK, Internet http://www.hukumonline.com/berita/baca/lt 5 948e3997c7ab/hak-angket-dpr-terhadap-kpk--sebuah-analisa-kritis-oleh-syamsuddin-radjab> diakses pada tanggal 12 Januari 2018 jam 16.50 WIB.

${ }^{6} \mathrm{Ni}^{\prime}$ Matul Huda, Hukum Tata Negara Indonesia, 2014, rajawali pers, Jakarta, hlm 107
} 
negara sesuai dengan rencana. Jika dikaitkan hukum pemerintahan, pengawasan dapat diartikan sebagai suatu kegiatan yang ditujukan untuk menjamin sikap pemerintah agar berjalan sesuai hukum yang berlaku. Dalam hukum tata negara, pengawasan berarti suatu kegiatan yang ditujukan untuk menjamin terlaksananya penyelenggaraan negara oleh lembaga-lembaga kenegaraan sesuai dengan hukum yang berlaku. ${ }^{7}$ Fungsi pengawasan secara konstitusional merupakan fungsi yang melekat pada legislatif seperti bunyi Pasal 20A UUD Tahun 1945. Pasal 20 A ayat (2) yaitu Dewan Perwakilan Rakyat memiliki fungsi legislasi, fungsi angga ran, dan fungsi pengawasan.

Menurut Undang-Undang Nomor 17 Tahun 2014 tentang Majelis Permusyawaratan Rakyat, Dewan Perwakilan Rakyat, Dewan Perwakilan Daerah, dan Dewan Perwakilan Rakyat Daerah (UU MD3) Pasal 79 ayat (3)

"Hak angket sebagaimana dimaksud pada ayat (1) huruf b adalah hak DPR untuk melakukan penyelidikan terhadap pelaksanaan suatu undang-undang dan/atau kebijakan Pemerintah yang berkaitan dengan hal penting, strategis, dan berdampakluas padakehidupan bermasyarakat, berbangsa, dan bernegara yang diduga bertentangan dengan peraturan perundang-undangan. "

Pasal 79 ayat (3) di atas dapat ditarik tiga kseimpulan bahwa hak angket dapat diterapkan apabila: 1) Berkaitan dengan pelaksanaan undang-undang dan/atau kebijakan Pemerintah; 2) Berkaitan dengan hal penting, strategis, dan berdampak luas pada kehidupan bermasyarakat, berbangsa dan bernegara; dan 3) Diduga bertentangan dengan peraturan perundang-undangan. Mengacu pada ketentuan pasal 791 ayat (3) tersebut di atas, apakah KPK digolongkan sebagai bagian dari lembaga eksekutif yang dapat diberikan Hak Angket oleh DPR itu yang menjadi permasalahan yang harus dibahas.

Secara subtansi, alasan DPR menggunakan Hak Angket terhadap KPK didasarkan pada Pasal 72 KUHAP, yang berbunyi sebagai berikut:

"Atas permintaan Tersangka atau Penasihat Hukumnya pejabat yang bersangkutan memberikan turunan berita acara pemeriksaan untuk kepentingan pembelaannya."

Salah satu terobosan hukum dalam penegasan penerapan Hak Angket DPR terhadap KPK ditandai dengan permohonan judicial review yang diajukan oleh Achmad Saifudin Firdaus dan rekan-rekan yang tergabung dalam Forum Kajian Hukum dan Konstitusi (FKHK) dan Horas A.M. Naiborhu selaku Direktur Eksekutif LIRA Institute sebagai pemohon dengan No. Perkara 36 dan 37/PUU-XV/2017 terkait dengan penerapan Hak Angket DPR kepada KPK. ${ }^{8}$ Atas perkara tersebut, Mahkamah Konstitusi dalam amar putusannya menolak permohonan para Pemohon untuk seluruhnya dalam putusannya.

\footnotetext{
${ }^{7}$ Sri Soemantri, Ketatanegaraan Indonesia Dalam Kehidupan Politik Indonesia : 30 Tahun Kembali ke Undang- undang Dasar 1945, pustaka sinar harapan. Jakarta, 1993, hlm.. 285

${ }^{8}$ http:// nasional.republika.co.id/berita/ nasional/hukum/, diakses 7 Juli 2018. Putusan Mahkamah Konstitusi No. Perkara 36 dan 37/PUU-XV/2017
} 
Majelis hakim berpendapat bahwa Komisi Pemberantasan Korupsi dibentuk untuk menjalani tugas penyelidikan, penyidikan, dan penuntutan tindak pidana korupsi. Tugas yang sebenarnya merupakan kewenangan kepolisian atau kejaksaan.

Dasar pembentukan KPK adalah belum maksimalnya kepolisian atau kejaksaan dan mengalami public distrust dalam memberantas korupsi. Dalam konstruksi demikian, tugas dan fungsi ketiganya berada di ranah eksekutif. KPK menurut hakim konstitusi termasuk ke dalam lembaga eksekutif yang melaksanakan fungsi eksekutif, yaitu penyelidikan, penyidikan, dan penuntutan. Karena itu, KPK dapat menjadi objek hak angket DPR dalam fungsi pengawasan.

Dilaporkan bahwa sebelum keputusan tersebut diambil, hakim MK terbelah dalam menolak permohonan uji materi terhadap Hak Angket KPK. Lima hakim menyatakan menolak permohonan Pemohon dan menyatakan hak angket KPK yang dibentuk DPR adalah sah. Hakim MK tersebut adalah Arief Hidayat, Anwar Usman, Aswanto, Wahiduddin Adams dan Manahan MP Sitompul. Sementara, empat hakim konstitusi lainnya menyatakan dissenting opinion atau perbedaan pendapat atas putusan tersebut. Empat hakim tersebut adalah Maria Farida Indrati, I Dewa Gede Palguna, Saldi Isra dan Suhartoyo. ${ }^{9}$ Perbedaan pendapat tersebut salah satunya dikemukakan oleh Hakim Konstitusi Maria Farida Indrati yang menyatakan bahwa KPK termasuk dalam ranah kekuasaan pemerintah (eksekutif) yang berdiri independen.

Walaupun KPK tidak bertanggung jawab terhadap Presiden secara lansung, dalam pelaksanaan tugas dan kewenangannya KPK bertanggung jawab kepada publik dan menyampaikan laporannya secara terbuka dan berkala kepada Presiden RI, DPR RI, dan BPK (vide Pasal 20 ayat (1) UU No. 30 Tahun 2002 tentang Komisi Pemberantasan Korupsi), sehingga tidak seharusnya KPK menjadi objek hak angket DPR.

Pakar Hukum Tata Negara, Yusril Ihza Mahendra menegaskan bahwa semua lembaga bisa menjadi objek hak angket DPR, tidak hanya KPK. Menurut Yusril, hak angket menjadi semacam kontrol terhadap lembaga-lembaga negara. Namun, dalam penggunaannya ada batasan-batasan tertentu. Pada konteks Mahkamah Agung (MA) misalnya, angket tidak dapat digunakan jika alasannya terkait materi perkara yang ditangani MA tapi dapat digunakan jika ada dugaan suap dalam urusan suatu perkara di MA. Dengan demikian, peranan hak angket hanya mencari fakta atas dugaan adanya suatu persoalan di suatu lembaga. Lebih lanjut Yusril mengatakan, rekomendasi yang dihasilkan dari penggunaan hak angket juga tidak berarti hanya diserahkan kepada pemerintah atau presiden, namun bisa diserahkan langsung kepada lembaga yang menjadi sasaran angket atau lembaga yang relevan menindaklanjuti rekomendasi tersebut. Dengan demikian KPK merupakan obyek yang sah untuk hak angket DPR. ${ }^{10}$

\footnotetext{
${ }^{9}$ http:// nasional.republika.co.id/berita/ nasional/hukum/, diakses 7 Juli 2018. Putusan Mahkamah Konstitusi No. Perkara 36 dan 37/PUU-XV/2017

${ }^{10}$ Novianti, Pusat Penelitian Badan Keahlian DPR RI, Kajian Singkat Terhadap Isu Aktual Dan Strategis, http://p u slit.dpr.go.id >Diakses tanggal 18 Juli 2018 Jam 20.45 WIB
} 
Berdasarkan uraian landasan hukum di atas dan Putusan Mahkamah Kostitusi No. Perkara 36 dan 37/PUU-XV/2017 yang bersifat final and binding, Yusril lebih lanjut menyatakan bahwa Hak Angket DPR terhadap KPK harus bisa memberikan dampak signifikan kepada KPK karena pada akhirnya hasil keputusan hak angket tetap dikembalikan kepada Presiden selaku pihak eksekutif yang mempunyai wewenang. Sehingga jangan sampai menjadi sebuah kesalahan ketika hak angket tersebut dialamatkan kepada KPK yang merupakan lembaga yang dibentuk oleh undang-undang dan bergerak independen.

\section{Alasan Penggunaan Hak Angket DPR Terhadap KPK}

Kinerja KPK selama ini mendapatkan penilaian yang baik dari masyarakat. Namun, hal tersebut tidak berarti bahwa prinsip transparansi dan akuntabilitas tidak perlu lagi menjadi perhatian, atau pengawasan tidak diperlukan lagi. Terlebih soal kaitannya dengan pelaksanaan tupoksi KPK. DPR (dalam hal ini Komisi III DPR RI) mendapatkan masukan dan informasi tentang tidak selalu berjalannya pelaksanaan tupoksi KPK tersebut sesuai peraturan perundang-undangan dan tata kelola kelembagaan yang baik.

Pokok materi angket merupakan kewajiban DPR untuk menjaga keberadaan KPK agar tak hanya kuat dalam melaksanakan tupoksinya namun juga KPK cermat dan memperhatikan seluruh ketentuan hukum maupun HAM dan menerapkan prinsip transparansi dan akuntabilitas yang benar dalam tata kelola termasuk terkait penggunaan anggaran. Serta adanya penyempurnaan terhadap pelaksanaan tugas dan wewenang KPK dalam penegakan hukum yang adil, transparan, akuntabel, profesional, proporsional sesuai ketentuan peraturan perundang-undangan. Jangan sampai upaya hak angket DPR RI tersebut sebagai bentuk penggiringan proses penegakan hukum ke dalam proses politik.

Alasan yang melatarbelakangi DPR RI melakukan Hak Angket terhadap KPK didasarkan pada empat (4) aspek yaitu aspek kelembagaan, kewenangan, tata kelola anggaran, dan tata kelola sumber daya manusia: ${ }^{11}$

1) Aspek Kelembagaan

a. KPK sebagai lembaga negara tidak disebut dalam UUD NRI Tahun 1945, melainkan dalam Undang-Undang Nomor 30 Tahun 2002 Tentang Pemberantasan Tindak Pidana Korupsi.

b. KPK Sebagai trigger mechanism, berarti mendorong atau sebagai stimulus agar upaya pemberantasan korupsi oleh lembaga-lembaga yang telah ada sebelumnya menjadi lebih efektif dan efesien. Komisi Pemberantasan Korupsi belum berhasil mengembangkan strategi penegakan hukum yang dapat mendorong dan memicu pemberdayaan lembaga penegak hukum lainnya.

${ }^{11}$ Pedoman Penyelidikan Panitia Angket DPR Atas KPK 
c. KPK bukan badan peradilan namun badan yang melaksanakan fungsi-fungsi pemerintahan dalam arti luas yaitu penyelidikan, penyidikan, dan penuntutan.

2) Aspek Kewenangan

a. Tugas dan wewenang KPK menghilangkan mekanisme Checks and balances dalam integrated justice system.

b. Peraktik tebang pilih dalam penanganan kasus tindak pidana korupsi.

c. Pelaksanaan tugas koordiansi, supervisi, dan monitoring. Berkaitan dengan pelaksanaan tugas KPK ini terdapat dua permasalahan, yaitu pertama, fungsi koordinasi dan supervisi KPK belum maksimal dan kedua, KPK belum berhasil menyusun jaringan kerja yang kuat dan memperlakukan institusi yang sudah ada menjadi counterpatner yang kondusif bagi pemberantasan korupsi.

d. Keberhasilan KPK dibandingkan dengan dengan instansi yang lainnya lebih karena kewenangan penyadapan yang tidak dimiliki oleh lembaga yang lainnya dan dukungan anggaran

e. Tugas pencegahan belum dilaksanakan secara efektif. Untuk menyelaraskan keorganisasian dan ketatalaksanaan di KPK, pelaksanaan pencegahan dan penindakan harus dilakukan secara bersinergi.

3) Aspek Anggaran

a. Anggaran dari APBN untuk KPK dan kerugian negara yang diselamatkan KPK. Seluruh kebutuhan dana oprasional KPK disediakan anggarannya dalam DIPA KPK yang bersumber dari APBN. Dalam melakukan pemberantasan korupsi, KPK mendapat anggaran yang lebih besar dari penyidik korupsi lainnya. KPK menggunakan anggaran yang lebih besar dari APBN dengan pagu senilai RP. 76 Juta dan hibah dalam bentuk jasa dalam tahun 2015 sebesar USD 5.152.109, AUD 1.300.000, dan EUR 7.950.000. Namun, besar uang negara yang dapat diselamatkan pada tahun 2016 sebesar Rp. 164 Miliar dan nilai suap sebesar Rp. 532.406.843.397.00. hal ini menunjukan bahwa anggaran yang dikeluarkan untuk KPK dan besaranya uang negara yang diselamatkan oleh KPK tidak proporsional.

b. Prinsip money follow function. KPK dalam mengadakan input yang di butuhkan KPK, telah sesuai dengan prinsip value for money untuk kriteria ekonomi. Hal ini dikarenakan pengadaan input tersebut telah melalui proses lelang selesai dengan peraturan berlaku, sedangkan pengukuran kriteria efesiensi KPK diukur dengan rasio antara output yang dihasilkan dengan input yang dihasilkan. Dalam menggunakan skema prespektif keuangan untuk mengikatkan kinerja, seharusnya KPK tidak menjadikan faktor ketersediaan anggaran sebagai indikator kinerjanya, tetapi sebaiknya KPK 
harus mempertimbangkan prinsip money follow function dalam pengelolaan aspek finansial. Prinsip tersebut terdiri dari kriteria ekonomi, efesiensi, dan efektivitas, sehingga setiap rupiah anggaran yang dikeluarkan oleh KPK dapat diketahui dampaknya terhadap pencapaian kinerja KPK dan memastikan Input yang didapatkan merupakan input yang paling ekonomis. Hal ini menunujakan bahwa KPK dalam penggunaan anggaran belum mempertimbangkan prinsip money follow function.

c. Kemudian pada Laporan Keuangan Pemerintah Pusat KPK Tahun 2016, tercatat 3 (Tiga) indikasi ketidakpatuhan terhadap peraturan perundangundangan terkait dengan:

a) Penerimaan Negara Bukan Pajak yaitu Pendapatan Jasa Giro terlambat disetor sebanyak Rp. 1.864.453.581,00 (Sekjen KPK selaku KPA belum mengajukan kepada pihak bank perihal mekanisme pelimpahan otomatis jasa giro ke Kas Negara dan sudah disetor pada 6 April 2017).

b) Permasalahan dalam kontrak belanja modal dengan total Rp. 2.566.390.108,00 yang terdiri dari kelebihan pembayaran yang disebabkan kekuarangan volume pekerjaan, ketidaksesuain spesifikasi teknis, dan keterlambatan penyelesaian pekerjaan yang belum dikenakan denda.

c) Permasalahan signifikan lainnya terkait belanja barang dengan total Rp.308.205.500,00 yang terdiri dari kurang pungut pph, kelebihan bayar, pemborosan konsumsi saksi, pertanggungjawaban yang tidak akuntabel, serta kelebihan pembayaran sewa ruangan.

4) Aspek Sumber Daya Manusia

a. Manajemen SDM di KPK mempunyai permasalahan secara regulasi.

b. Indikator integritas zero tolerance tidak tercapai. Dalam prespektif pembelajaran dan pertumbuhan, seluruh indicator kinerja dapat tercapai bahkan melebihi 100\% kecuali pembangunan gedung KPK. Meskipun dalam penetapan indicator integritas yang zero tolerance tidak tercapai karena selalu ada pegawai KPK yagn mendapatkan sanksi karena melanggar kode etik.

c. Indikator pengelolaan pegawai hanya fokus pada satu unsur are kompetensi. Hal penting yang ditekankan mengenai manajemen sumber daya manusia di KPK adalah keharusan pimpinan KPK untuk berkoordinasi dengan pimpinan instansi asal pegawai yang dipekerjakan di KPK. Dalam implementasinya terdapat beberapa permasalahan antara lain indokator pengelolaan sumber daya manusia yang ditetapkan oleh KPK hanya satu unsur saja, yaitu kompetensi sesuai fokus area. 
Berdasarkan ketentuan dalam UUMD3 serta putusan Mahkamah Konstitusi No. Perkara 36 dan 37/PUU-XV/2017 yang menyatakan bahwa makna pemerintah meliputi fungsi eksekutif KPK memiliki konsekuensi Yuridis terhadap daya ikat Hak Angket DPR RI terhadap KPK. KPK sebagai institusi penegak hukum harus menghormati putusan MK dan melaksanakan putusan MK terkait keabsahan Hak Angket DPR RI serta melaksanakan rekomendasi yang telah dihasilkan Pansus Angket DPR RI tersebut.

Berdasarkan hasil penyelidikan panitia angket DPR RI tentang pelaksanaan tugas dan kewenangan KPK, muncul keputusan untuk merekomendasikan berbagai agenda penguatan KPK pada pada Rapat Paripurna ke-18 masa persidangan III tahun sidang 2017-2018 di Kompleks Parlemen, Senayan, Jakarta, Rabu (14/2/2018). Antara lain aspek kelembagaan, kewenangan, anggaran dan tata kelola SDM. Ketua Pansus Hak Angket KPK Agun Gunanjar Sudarsa menuturkan sebagai berikut: ${ }^{12}$

Pertama kelembagaan, Pansus meminta KPK untuk menyempurnakan struktur organisasi KPK agar mencerminkan tugas dan kewenangan sebagaimana diatur dalam Undang-Undang Nomor 30 Tahun 2002 tentang Komisi Pemberantasan Korupsi. Pansus meminta KPK meningkatkan kerja sama dengan lembaga penegak hukum serta lembaga lainnya, seperti BPK, LPSK, PPATK, Komnas HAM, dan pihak perbankan dalam menjalankan upaya pemberantasan korupsi agar optimal, terintegrasi, dan bersinergi dengan baik. Pansus juga merekomendasikan pembentukan lembaga pengawas independen. KPK disarankan melalui mekanisme yang diatur sendiri oleh KPK membentuk lembaga pengawas independen yang beranggotakan dari unsur internal KPK dan eksternal yang berasal dari tokoh-tokoh yang berintegritas dalam kerangka terciptanya check and balances.

Kedua kewenangan, Pansus merekomendasikan agar KPK berkoordinasi dengan pihak Kepolisian dan Kejaksaan. KPK harus menempatkan kepolisian dan kejaksaan sebagai counterpartner yang kondusif sehingga pemberantasan korupsi dapat dilaksanakan secara efektif dan efesien. Dalam menjalankan tugas penyelidikan, penyidikan, dan penuntutan terhadap tindak pidana korupsi, KPK diminta lebih memperhatikan prinsip-prinsip hak asasi manusia dan mengacu pada hukum acara pidana yang berlaku serta memperhatikan pula peraturan perundang-undangan lainnya.

Ketiga aspek anggaran, Pansus meminta KPK untuk meningkatkan dan memperbaiki tata kelola anggarannya sesuai dengan hasil rekomendasi dari BPK. DPR RI akan mendorong peningkatan anggaran KPK untuk mengoptimalkan penggunaan anggaran tersebut dalam fungsi pencegahan, seperti pendidikan, sosialisasi, dan kampanye antikorupsi, sehingga dapat memberikan pemahaman yang lebih komprehensif kepada masyarakat dengan harapan berkurangnya kasus korupsi pada masa yang akan datang.

\footnotetext{
${ }^{12}$ https://nasional.kompas.com/read/2018/02/14/13445731/ini-rekomendasi-lengkap-pansus-angket terhadap-kpkpage=all> Diakses tanggal 25 Juli 2018 Jam 19.20 WIB
} 
Keempat, tata kelola Sumber Daya Manusi, KPK diminta memperbaiki tata kelola SDM dengan memperhatikan peraturan perundang-undangan di bidang SDM/ kepegawaian. Proses pengangkatan, promosi, mutasi, rotasi, hingga pemberhentian SDM KPK harus semakin transparan dengan mengacu pada UU tentang aparatur sipil negara, kepolisian, dan kejaksaan. Dalam kurun waktu lima tahun, KPK harus mampu meningkatkan Indeks Persepsi Korupsi, menetapkan arah kebijakan penegakan hukum pemberantasan yang sejalan dengan program pembangunan Pemerintah, dan menindaklanjuti temuan pansus bersama-sama aparat penegak hukum lainnya.

Menurut pengamat Hukum Tata Negara dari Universitas Parahyangan Bandung, Asep Warlan Yusuf, putusan Mahkamah Konstitusi atas penggunaan hak angket DPR diharapkan dapat menjadi arahan dan rujukan untuk keputusan ke depan. Maksudnya, apakah Hak Angket tersebut dapat ditujukan atau tidak pada lembaga-lembaga selain Presiden. Warlan juga meminta, agar Komisi Pemberantasan Korupsi selaku pemohon uji materi Pansus Hak Angket dapat memastikan bahwa sistem atau aturan yang ada telah benar. Oleh karena itu, KPK sebagai lembaga negara perlu dikoreksi dan dievaluasi. ${ }^{13}$

DPR sebagai wakil rakyat berhak meminta pertanggungjawaban pelaksanaan tugas dan kewenangan KPK, meski KPK juga bertanggung jawab kepada publik. Untuk itu, penggunaan hak angket terhadap KPK juga harus dilihat sebagai bentuk penguatan terhadap KPK dan penegakan hukum dalam hal pemberantasan korupsi yang transparan, akuntabel, adil dan non-diskriminasi. Hak angket merupakan hak DPR yang konstitusional untuk mengontrol kerja KPK secara politik. Hal itu dilakukan DPR untuk memastikan apakah KPK telah tebang pilih atau tidak, dalam pemberantasan korupsi.

Selain itu, pengawasan DPR melalui hak angket terhadap KPK tidak berarti menunjukkan sebuah ketidakpercayaan atau (distrust) terhadap KPK, juga tidak berarti sebagai bentuk upaya pelemahan, melainkan dapat menjadi upaya menjaga KPK dari segala bentuk penyalahgunaan wewenang dan menjaga KPK agar tetap menjalankan tugas dan fungsinya sesuai amanat undang-undang yang membentuknya.

\section{Simpulan}

Sesuai filosofi dasar negara Indonesia dari keberadaan tiga kekuasaan dalam pemerintahan yaitu kekuasaan eksekutif, legislatif dan yudikatif, esensi dari interaksi antara eksekutif dan legislatif melalui fungsi pengawasan haruslah ditempatkan dalam bingkai mekanisme cheks and balances dalam penyelengaraan pamerintahan. Landasan hukum penggunaan hak angket DPR terhadap KPK secara konstitusional diatur di dalam Pasal 20A UUD NRI Tahun 1945. DPR sebagai lembaga legislatif yang merupakan salah satu cabang kekuasaan mempunyai fungsi pengawasan dan mempunyai hak yaitu Hak Interpelasi, Hak Angket dan Menyatakan pendapat.

13 Novianti, Pusat Penelitian Badan Keahlian DPR RI, Kajian Singkat Terhadap Isu Aktual Dan Strategis, http://p u slit.dpr.go.id >Diakses tanggal 18 Juli 2018 Jam 21.00 WIB 
Pengaturan lebih lanjut terdapat dalam Undang-Undang Nomor 17 Tahun 2014 Pasal 79 ayat (3). Mengatur bahwa penggunaan hak angket DPR pada dasarnya merupakan hak kelembagaan DPR yang diberikan oleh undang-undang untuk melakukan penyelidikan terhadap pelaksanaan suatu undang-undang dan/atau kebijakan pemerintah yang berkaitan dengan hal penting, strategis, dan berdampak luas pada kehidupan bermasyarakat, berbangsa, dan bernegara yang diduga bertentangan dengan peraturan perundang-undangan. Berdasarkan Putusan MK No. Perkara 36 dan 37/PUU-XV/2017, MK menyatakan bahwa makna pemerintah tersebut termasuk fungsi eksekutif KPK. Putusan MK yang menolak permohonan uji materi terkait keberadaan Hak Angket KPK dinilai mempertegas keberadaan DPR sebagai lembaga yang melakukan fungsi pengawasan. latar belakang DPR melakukan Hak Angket Terhadap KPK ada empat (4) aspek: Pertama kelembagaan yaitu KPK belum berhasil mengembangkan strategi penegakan hukum yang dapat mendorong dan memicu pemberdayaan lembaga penegak hukum lainnya. Kedua kewenangan yaitu fungsi koordinasi dan supervisi KPK belum maksimal dan KPK belum berhasil menyusun jaringan kerja yang kuat dan memperlakukan institusi yang sudah ada menjadi counterpatner yang kondusif bagi pemberantasan korupsi. Ketiga tata kelola anggaran yaitu anggaran dari APBN untuk KPK dan kerugian negara yang diselamatkan oleh KPK tidak proporsional. Keempat tata kelola sumber daya manusia yaitu Indikator integritas zero tolerance tidak tercapai karena selalu ada pegawai KPK yang mendapatkan sanksi karena melanggar kode etik.

Berdasarkan Putusan MK No. Perkara 36 dan 37/PUU-XV/2017 yang bersifat mengikat membawa implikasi bahwa KPK sebagai lembaga penegak hukum harus menghormati dan melaksanakan rekomendasi yang telah dihasilkan pansus angket tersebut. Selain itu, DPR sebagai wakil rakyat berhak meminta pertanggungjawaban pelaksanaan tugas dan kewenangan KPK. Pengawasan DPR melalui hak angket tidak berarti sebagai bentuk upaya pelemahan atau ketidakpercayaan terhadap KPK. Namun harus dilihat sebagai bentuk pengawasan DPR dalam menjaga keberadaan KPK agar tak hanya kuat dalam melaksanakan tupoksinya namun juga KPK cermat dan memperhatikan seluruh ketentuan hukum dan HAM serta menerapkan prinsip transparansi dan akuntabilitas yang benar dalam tata kelola termasuk terkait penggunaan anggaran.

\section{Daftar Pustaka}

\section{Buku}

Assdiddiqie, Jimly, 2010, Pengantar Ilmu Hukum Tata Negara, Jakarta: Rajawali Pers Budiardjo, Miriam, 1978, Dasar Dasar Ilmu Politik, Jakarta : Gramedia.

Huda, Ni"matul, 2001, Hukum Tata Negara Indonesia, Jakarta : PT Raja Grafindo

Persada. 
Muhammad, Erwin, 2011, Pendidikan Kewarganegaraan Republik Indonesia, Bandung : PT Refika Aditama.

Soemantri, Sri. dkk, 1993, Ketatanegaraan Indonesia Dalam Kehidupan Politik Indonesia 30 Tahun kembalike Undang-Undang Dasar 1945, Jakarta : Pustaka Sinar Harapan. Tim ICCE UIN Jakarta, 2003, Pendidikan Kewarganegaraan (Civic Education) Demokrasi, Hak Asasi Manusia dan Masyarakat Madani, Jakarta : Prenada Media.

Wahjono, Padmo, 1983, Indonesia Negara Berdasarkan Atas Hukum, Jakarta : Ghalia Indonesia.

\section{Perundang-Undangan}

Undang-Undang Dasar Negara Republik Indonesia Tahun 1945.

Undang-Undang Nomor 17 Tahun 2014 Tentang Majelis Permusyawaratan Rakyat, Dewan Perwakilan Rakyat, Dewan Perwakilan Daerah, dan Dewan Perwakilan Rakyat Daerah

Putusan MK No. Perkara 36 dan 37/PUU-XV/2017

\section{Internet}

Novianti, Pusat Penelitian Badan Keahlian DPR RI, Kajian Singkat Terhadap Isu Aktual dan Strategis, <http://p u slit.dpr.go.id > Diakses tanggal 18 Juli 2018 Jam 21.00 WIB.

Syamsudin, Hak Angket DPR Terhadap KPK, Internet <http://www.hukumonline.com/ berita/baca/lt5948e3997c7ab/hak-angket-dpr-terhadap-kpk--sebuah-analisa-kritis-oleh-syamsuddin-radjab> diakses tanggal 12 Januari 2018 jam 16.50 WIB. 